\title{
Anti-Corruption Enforcement and Organizations: A Narrative Review
}

\author{
Enforcement Anticorrupção e Organizações: Uma Revisão Narrativa
}

\author{
Robson Fernandes Soares*1 \\ Edson Ronaldo Guarido Filho ${ }^{10}$
}

\section{ABSTRACT}

Context: in the administration literature, it is possible to identify several occurrences of the term enforcement, mainly related to studies of corruption. These mentions, however, are not uniform and often refer to different types of the phenomenon. In addition, they occur without connection to regulation studies, in which enforcement is a central concept. Objective: the objective of the present study is to identify the types of anticorruption enforcement present in the administration literature in the light of the regulatory literature. Methods: we carried out a reflective thematic analysis on 31 articles in the administration area, selected in the Web of Knowledge database and published until 2017, in which corruption and enforcement appear in a related way. Results: at the end of the analysis, it was possible to identify four types of occurrence of the term in the literature: punitive, market, competitive, and cultural enforcement. These four types have unique characteristics in the light of the regulatory literature. Conclusions: the identification of types of anti-corruption enforcement contributes to differentiate the many ways in which the term is used in the literature. Furthermore, as a study of a typological nature, it offers a way to develop new theories, as well as to carry out empirical studies.

Keywords: enforcement; corruption; organizations.
* Corresponding Author.

1. Universidade Positivo, Programa de Mestrado e Doutorado em Administração, Curitiba, PR, Brazil.

Cite as: Soares, R. F., \& Guarido Filho, E. R. (2021). Anti-comuption enforcement and organizations: A narrative review. Revista de Administração Contemporânea, 25(6), el90149. https://doi.org/10.1590/1982-7849rac2021 190149.en

\section{RESUMO}

Contexto: na literatura de administração é possível identificar diversas apariçóes do termo enforcement, principalmente relacionadas aos estudos de corrupção. Essas mençóes, contudo, não são uniformes e muitas vezes dizem respeito a tipos diferentes do fenômeno. Além disso, elas ocorrem sem conexão com estudos de regulaçáo, na qual o enforcement é conceito central. Objetivo: o objetivo do presente estudo é identificar os tipos de enforcement anticorrupçáo presentes na literatura de administração à luz da literatura de regulaçáo. Métodos: foi realizada análise temática reflexiva de 31 artigos da área de administraçáo selecionados na base de dados Web of Knowledge publicados até 2017 nos quais corrupção e enforcement aparecem de forma relacionada. Resultados: ao término da análise foi possível identificar quatro tipos de aparição do termo na literatura: enforcement punitivo, de mercado, competitivo e cultural. Esses quatro tipos apresentam características únicas à luz da literatura de regulação. Conclusóes: a identificação dos tipos de enforcement anticorrupção contribui para a diferenciação das diversas formas em que o termo é empregado na literatura. Além disso, como estudo de natureza tipológica, oferece caminho para o desenvolvimento de novas teorias, bem como para a realização de estudos empíricos.

Palavras-chave: enforcement; corrupção; organizações.

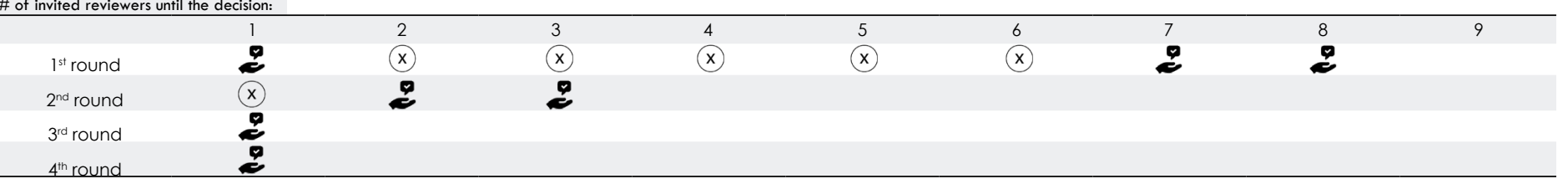




\section{INTRODUCTION}

In studies in the management field it is possible to identify several paradigms of analysis, many with entirely opposite assumptions (Burrel, 2006). This diversity of paradigms can be attributed to the own formation of management thought, which, as applied science, is inspired by models of other sciences, such as economics, sociology, and psychology. In many cases, the theoretical sciences paradigms are compatible, but in others, there is a real conflict (Gioia \& Pitre, 1990).

One of the incompatibilities between paradigms lies in the way they understand certain terms, which assume very different meanings according to the implicit theoretical and epistemological background (Shepherd \& Challenger, 2013). This situation becomes problematic when there is an indiscriminate and nonsituated use of the same terms to refer to different situations, causing ambiguities.

These ambiguities are recurrent in the business literature, often producing conceptual confusions, characterized by the construction of theoretical frameworks with indiscriminate conjugation of the terms belonging to several theoretical lines (Matitz \& Vizeu, 2012). A particular case of this situation can be observed in administration studies related to enforcement.

In some works, enforcement is employed as a degree of importance that individuals give to standards (Vitell \& Hidalgo, 2006). In others, enforcement is associated with control agencies that act on organizations (Jia, Ding, $\mathrm{Li}, \& \mathrm{Wu}, 2009)$. There are also those who associate enforcement with disputes or conflicts exercised in disfavor of companies (Bakos \& Dellarocas, 2011). Finally, there are those that make references to corrective actions to deal with transaction problems (Mooi \& Gilliland, 2013).

In addition to this range of the term's meaning, it is possible to find approaches based on opposing paradigms. There are works that treat enforcement in an utilitarian logic, conceiving it as punitive mechanism of individual coercion (Becker, 1968); other studies conceive enforcement in a constructivist logic, as a mechanism capable of promoting behavioral transformations through changes in the mental model of agents (Fisman \& Miguel, 2007). As a result, it is shown as relevant issues to distinguish the types of enforcement from legal or social norms, as well as the logics of action associated with each type (Kaczmarek \& Newman, 2011).

A rich field to study the many usages of the term is management studies related to corruption. This is because the recent phenomenon of fighting corruption has conducted regulatory proliferation both internationally
(Carr, 2007) and nationally (Carson \& Prado, 2014) that has had difficulties to result in effective practical effects (Heeks \& Mathisen, 2012). This difficulty has driven studies that seek more effective alternatives for anti-corruption enforcement (Batory, 2012). This search makes the term enforcement to be repeatedly explored in the most diverse approaches by academic works.

In the literature, it was not found any systematization or typification about the different occurrences of anticorruption enforcement. We also did not find works that related these term apparitions with regulatory literature, in which enforcement is a central concept. In order to invest in this gap, the present work aims to identify the types of anti-corruption enforcement present in the administration literature in the light of the regulatory literature. This kind of work has relevance by its knowledge systematization, and is important to highlight different uses and assumptions of the term and support further theoretical and empirical developments.

For this, we initially carry out the discussions on enforcement in regulatory literature. The two paradigmatic models in the literature (coercion vs. persuasion) are presented, and then we discuss the refinements that led to the enforcement typologies in this area. Then, we make considerations about corruption and the anti-corruption movement in organizations, as well as on typological studies in administration. This paper continues presenting the methodological procedures for literature selection and comprehensive thematic analysis. Next, we present the four types of enforcement found in the literature and perform the contextualization of these types in the light of the regulatory literature. Finally, we have the general discussion, in which we make a brief synthesis of the work and offer contributions of this article for future studies.

\section{THEORETICAL REVIEW}

The term enforcement is not used uniformly in the regulatory literature. Sometimes it is employed to refer to the actions of the control agents to ensure compliance with some desired standard of conduct. Other times it is employed as the mechanisms that lead certain social agents to adopt behaviors in accordance with the standard of conduct (Kagan, 1989; May \& Burby, 1998). In the present work, we adopt this second definition due to its conceptual scope, in which enforcement is understood as the process that induces compliance with a norm, whether moral or legal, written or implicit. In the following sections, we present the main discussions of the area of regulation, according to the perspective employed here. We also present considerations about the anti-corruption 
movement in organizations and on typological studies in administration.

\section{Agent behavior and enforcement strategies}

Studies on regulation have been based on two types of enforcement strategies: (a) coercion strategy; and (b) persuasion strategy. Coercion studies are based on the imposition of sanctions to inhibit the violation of a standard, while studies on persuasion seek in actions of education, negotiation, and cooperation the means to ensure compliance (Frank, 1984).

It is possible to attribute these differences of approach to the assumptions about the human nature that the theorists of each line adopt. In the coercive line, rational agents are assumed and, therefore, the decision to obey a standard is the result of a calculus of the utility maximization, in which the agent considers exclusively the benefits and costs of disobedience to make his decision (Polinsky \& Shavell, 2000). On the other hand, there is the constructivist approach, which understands that social agents do not necessarily disobey a norm intentionally and rationally, but for other reasons, such as ambiguity of the norm itself, not internalization of normative values, or even ignorance (Voermans, 2014).

The coercive approach applies to the logic that the agent will act in accordance with a standard whenever the potential costs of disobedience are higher than the gains obtained from the infraction (Gunningham, 2010). Thus, basically, the mainly idea consists of creating sanctions high enough and with adequate detection rates so that the violation of a standard becomes economically irrational from a utilitarian point of view (Cohen, 2000).

On the other hand, in the constructivist approach, it is argued that agents seek conformity either because there is a sense of social responsibility and adherence to the prevailing moral standards, or because they are subject to external factors such as market forces, image, or obligations with third parties (Rechtschaffen, 1997). In this sense, actions of self-enforcement, in which agents seek to identify and correct their own deviations, are a demonstration of the desire for compliance with the normative standards of the environment (Helland, 1998). Thus, the objective of enforcement is to ensure that the need for compliance with the norm is internalized in the agent's mental model, regardless of the pecuniary punishments involved (Glicksman \& Earnhart, 2006).

The literature is vast on the effects of coercive enforcement to curb behaviors that swerve from a pattern of conduct (Gray \& Shimshack, 2011). In relation to the effects of persuasive enforcement, there is a smaller number of empirical studies, with less evidence as to how effective this enforcement approach is (Earnhart \& Glicksman, 2015). On the other hand, it is argued that a very strong coercive enforcement can trigger a process of resistance, turning the intention of voluntary compliance less likely (Kirchler, 1999). As a result, in certain situations, coercive enforcement takes the form of a $U$ inverted, generating positive effects as it increases, but becoming harmful when it exceeds a tolerable enforcement point (Liu, Van Rooij, \& Lo, 2018).

\section{Enforcement typologies}

The discussion between coercive and persuasive enforcement came to be seen by literature as two extremes in a continuum that had a diversity of styles, with characteristics of both coercion and persuasion (Gormley, 1998). Several refinements of this initial discussion were proposed in the literature, which eventually generated interesting distinctions to understand the phenomenon. Two of them are the most recurrent and so are treated here. They are the distinctions between public and private enforcement and between formal and informal enforcement. A more detailed discussion of other forms of classification can be found in Liu, Van Rooij and Lo (2018) and McAllister (2010).

Formal enforcement is based on legal control mechanisms, while informal enforcement is based on social control mechanisms (Armour, 2008; Frank, 1984). Public enforcement is that performed by a government agent, while private enforcement is that performed by a market-owned agent (Hay \& Shleifer, 1998). Although it is possible to draw parallels between the coercive approach and formal and public enforcement and between the persuasive approach and private and informal enforcement, these classifications are not dependent.

In the formal approach, it is seek the creation of incentives or inhibitions in formal laws or rules, so that the existence and application of these mechanisms serve as a behavior inducer (Galbiati \& Vertova, 2014). On the other hand, much of social cohesion comes not from the application of laws, but from the force exerted by informal mechanisms of social enforcement. These unusual mechanisms can be punitive, such as negative gossip and ostracism, or rewarding, such as respect, reputation, or better trading opportunities (Ellickson, 1998).

This type of social enforcement is guaranteed by the repeated interaction of agents, in which, through socialization processes, cooperative behaviors are induced and internalized (Posner, 2002). Repeated interaction is important because there is learning about past behavior, as 
well as the possibility of applying reprisals to opportunistic behavior, which is not possible in interactions of only a single event.

Furthermore, there is an interaction between formal and informal mechanisms, since the application of formal rules, if poorly designed, can affect the dynamics of social enforcement and induce conflict (Kube \& Traxler, 2011). Just as the typology punishment/persuasion acts in a continuum, the formality of the mechanisms also varies, with rigid rules at one end, passing through guiding principles, until the other extreme with no written rules.

The other discussion between public and private enforcement is related to the ability of private agents to resolve their conflicts properly without state intervention. In general, it is argued in favor of public enforcement - firstly, claiming that it is economically unfeasible for a private institution to maintain a procedural and enforceable system of the rules, and, secondly, because there is a view that the use of force is a state monopoly (Polinsky \& Shavell, 2007). It is worth saying that this conception is, however, very associated with the punitive perspective of enforcement.

On the other hand, there are also arguments in favor of private enforcement. For that, it is argued that non-governmental institutions have fewer bureaucratic obstacles in execution, in addition to being financed with private resources, thus not burdening the public budget
(Burbank, Farhang, \& Kritzer, 2013). In addition, the private enforcement system could submit to competition, and thus be less susceptible to regulatory capture (Garoupa \& Klerman, 2010).

This private enforcement can be performed by independent private entities, such as arbitration chambers, certification bodies, and unions (Hay \& Shleifer, 1998). However, it can also be performed by internal organizational mechanisms, such as the board of directors and governance bodies. This conception of internal private enforcement has a certain relationship with the idea of corporate governance (Williamson, 1996).

Although public enforcement is traditionally linked to a formal dimension and private enforcement to informal dimension, this association is not true, once there are public enforcement mechanisms that are informal and formal mechanisms for private enforcement (Armour, 2008). Similarly, it is also possible to conceive this duality in a continuum, which varies from an exclusively stateowned action, passing for a mixed enforcement, to an enforcement exclusively carried out within the private sphere.

In the following table, it is possible to make a synthesis of the main dimensions presented by the enforcement literature. These characteristics do not always appear well outlined in studies dealing with the theme.

Table 1. Enforcement typologies.

\begin{tabular}{ccc}
\hline Dimension & Description & Continuums of ideal types \\
\hline Strategy & What is the mechanism of action? & Coercive $\leftarrow \rightarrow$ Persuasive \\
Agent & Who is responsible? & Public $\leftarrow \rightarrow$ Private \\
Relationship & How flexible is the application? & Informal $\leftarrow \rightarrow$ Formal \\
\hline
\end{tabular}

Note. Source: own elaboration.

These typologies allow establishing the main aspects involved in the configuration of enforcement mechanisms. In this sense, as for the responsible (agent) for enforcement, he may be a public agent, a private agent, or a mixture of these two. About the approach (strategy) that this agent can use to induce enforcement, it can be exclusively punitive, exclusively persuasive, or something that combines both aspects of punishment and persuasion. Finally, the implementation (relationship) of this strategy can be through a formal or informal framework of action, or something with aspects that combine these two characteristics.

\section{Corruption and anti-corruption movement in organizations}

Before discussing the appearances of enforcement in the anti-corruption literature, it is necessary to carry out a brief contextualization of corruption and the anti-corruption movement in organizations. Corruption has been pointed out by literature as being harmful and dysfunctional to society, constituting a broad social problem (Torsello \& Venard, 2016). The negative consequences of corruption, 
however, are not limited to the social plane. Studies in the area of administration have analyzed the deleterious effects of corruption also for organizations. Among possible consequences that it can bring to companies, we can list reputational damage, the risks of punishment, the loss of competitiveness, transaction costs, and the creation of an unethical organizational culture (Luo, 2005). Because of this, business literature has also associated corruption with a negative connotation, labeling it as the dark side of organizations (Linstead, Maréchal, \& Griffin, 2014).

The need to deal with these negative aspects for organizations has fostered a growing literature on both organizational corruption and organizational anticorruption efforts (Pertiwi, 2018). The works have been focused on understanding corruption at the level of the people in organizations (micro plane) as well as on disseminated corruption in the organizational structure (macro plan) (Ashforth, Gioia, Robinson, \& Trevino, 2008). The evidence has shown that these two aspects are not only correlated but also generate negative impacts on organizational performance (Katou, 2013).

To better combat these harms, the works have sought to understand the factors that contribute to the occurrence of corruption. These factors are classified as internal or external to the organization (Pinto, Leana, \& Pil, 2008). Internal causes include incentive structure, aggressive culture, and lack of controls (Galang, 2012). Among the external causes are the structure of industry competition, regulation, and institutional pressures (Luo, 2005).

Due to these multiple causes, multiple responses have been proposed, such as regulatory changes, hardening of legal application, incentives for the adoption of anti-corruption control systems, among others (Osuagwu, 2012). However, many of these changes, especially those resulting from state action, have proved innocuous, often because they disregard the dynamics of control mechanisms or because they run into budgetary limitations (Heeks \& Mathisen, 2012).

Fortunately, the management literature has contributed to the proliferation of studies addressing multidimensional anti-corruption mechanisms. In this sense, it has been studied formal and informal control mechanisms, focused on processes or results and that consider several agents of interest (Lange, 2008). It is worth highlighting that in these studies also permeates the discussion about organizational enforcement, which is why this literature is rich to understand this phenomenon.

\section{Typologies in administration}

Typologies have been important in the administration literature as a way for the development of organizational theories (Delbridge \& Fiss, 2013). This is because theories intend the description, explanation, and prediction of phenomena, and typologies find a place as useful tools both to describe and explain phenomena (Snow \& Ketchen, 2014). In this sense, it is possible to mention several organizational theories that originated in typological studies, such as Porter's (1980) theory of competitive advantage, based on the ideal types of strategies, and Mintzberg's (1979), theory of organizational structures, anchored in the ideal types of organizational structure.

At this point, it is worth mentioning that typologies are not simple classification schemes. Classification schemes are decision rules that have the function of categorizing phenomena into mutually exclusive and exhaustively categories. Typologies, on the other hand, do not offer rules of decision, but ideal types of phenomenon, which describe a combination of attributes (Doty \& Glick, 1994). As a result, typologies are based on consistency logics, that is, they are usually constructed and evaluated in the notion of adjustment between the different parts that make up the ideal type or configuration (Fiss, 2011). Consequently, typologies have a higher degree of abstraction.

This greater degree of comprehensiveness and abstraction, however, does not transform them into theories, because it is not for typologies to answer questions such as why, how, in what way (Bacharach, 1989). On the other hand, typologies are a starting point for theories construction, since, from them, theoretical relationships can be proposed, hypotheses can be formulated, metrics can be developed, and relationships can be tested. Thus, typologies consist of an excellent tool to discuss already consolidated theories, as well as to understand and form theories on emerging themes (Snow \& Ketchen, 2014). In this aspect, the typological construction work carried out here finds relevance.

The construction of typologies consists of a more complex activity than the creation of classification schemes. This construction involves the identification of the relevant dimensions, followed by the specification of the ideal types, aiming at the understanding and explanation of phenomena (Niknazar \& Bourgault, 2017). There are three most recurrent approaches: (a) proposition based on a theory; (b) proposition based on continuum; and (c) proposition based on statistical tests (Doty \& Glick, 1994). In the present work, we opted for a typological development based on continuums of the regulation theory.

To construct the present typology, we initially seek to identify the occurrences of the theme in the administration literature, as already done in previous typology studies, such as in Miles, Snow, Meyer and Coleman (1978). In this work, the authors developed their typology with a sample of 16 university book publishers, justifying that they could thus understand the thought in relation to the organizational 
forms present in the industry. Based on this approach, the authors identified four ideal types of organizations (prospecting, defenders, analyzers, and reactors).

Based on this perspective of typological development, the present work reviewed the works on the theme in order to serve as a starting point for the construction of typology. From this review, the appearances of the anti-corruption enforcement theme were analyzed using thematic analysis. Based on thematic analysis and on the enforcement typologies of the regulatory literature, the typology proposed here is contextualized. This approach is consistent with other works that develop typologies within theoretical schemes (Niknazar \& Bourgault, 2017).

\section{METHODOLOGICAL PROCEDURES}

In this section, we present the methodological considerations that allowed the identification of the types of anti-corruption enforcement present in the administration literature. For this, we discuss the way of selecting the works used for analysis and the technique of thematic analysis applied.

\section{Selection of works}

To select the papers, it was done a research in the Web of Science database using combinations of the words 'corrupt"' and 'enforcement.' We searched these terms in the topic, which considers title, summary, and keywords. This parameter resulted in 673 publications. The research was then restricted to journals in the areas of 'economics,' 'business,' 'public administration,' 'business finance,' and 'management' published until 2017. This filter resulted in 121 publications. Following, we selected only articles, resulting in 87 papers. It must be highlighted that this type of methodological analysis, as well as the use of that database, is recurrent in studies to review the administration literature (Crossan \& Apaydin, 2010).

Later, we read the abstracts of these 87 papers. We eliminated articles in which corruption and enforcement were related only as independent variables to describe the national business environment, without theoretical considerations relating the two variables. We also eliminated articles that presented only the evolution of legislation or organizations related to the fight against corruption. After this initial filter, 31 articles remained. Using the reference base of these 31 articles on the Web of Science, we performed a cocitation analysis using the VOSviewer software to identify the main references related to the articles. We used these references to assist the thematic analysis of the 31 selected articles.

\section{Thematic analysis}

Thematic analysis is a method for identifying, analyzing, and interpreting patterns of meanings (themes) in qualitative data (Clarke \& Braun, 2017). This technique can be divided into two strands: top down and bottom up. In the top-down approach, the goal is to define themes informed by the theory and apply them to the data. In the bottom-up approach, the goal is to develop inductively the themes from the data (King, 2012). Thus, it is possible to say that the top-down approach has analytical orientation with objectivist nature and the bottom-up has exploratory orientation with subjectivist nature (Clarke \& Braun, 2017).

In management literature, it is possible to identify a series of applications of this technique to analyze the most diverse data sources. In an illustrative way, it is worth mentioning some studies, which, as in the present research, applied this technique to documentary data. Radcliffe (2013), for example, used thematic analysis in couples' diaries to identify decision patterns in family life. Conaway and Wardrope (2010) used thematic analysis to identify the most common topics in management reports published by businesses. Lane, Koka and Pathak (2002) applied thematic analysis to articles to map the main research topics on absorptive capacity of organizations.

Similarly, this technique can serve a diversity of purposes, including supporting the creation of typologies. An example of study in this sense is Jabareen (2006), which used thematic analysis to identify a typology in the literature of sustainable urban forms. In the same direction Kusyk and Lozano (2007) Kusyk and Lozano (2007) used thematic analysis to identify a typology of corporate social responsibility for small- and medium-sized enterprises. Finally, Caza (2012) used the technique to identify a typology of eight domains of organizational discretion.

\section{Analysis procedure}

Regarding the method of application, several variations are found in the literature. A summary of these variations is presented by King and Brooks (2018), who classify thematic analyses into four styles: (a) template analysis, (b) reflective analysis, (c) framework analysis, and (d) matrix analysis. Of the four styles mentioned, the reflective analysis is bottom up and the other three are top down. Due to the inductive exploratory character aimed in the present study, it was decided to use the reflexive approach, which has as its greatest exponents Braun and Clarke (2006).

The authors propose the development of the analysis in six stages, which are discussed and contextualized below: 
1. Familiarization with the data: The researcher should dive into the data and seek to become familiar with it (Clarke \& Braun, 2013). This phase was performed with the full reading of the 31 articles selected for analysis.

2. Initial generation of categories (coding): In reflexive analysis, rather than trying to frame data into codes from pre-existing themes, the goal is to use the codes as guides to try to find implicit themes (Braun \& Clarke, 2006). For this purpose, it is possible to develop a semantic analysis, focused on explicit meanings, or a latent analysis, focused on implicit concepts (Terry, Hayfield, Clarke, \& Braun, 2017). The present research used the (continuums) categories of enforcement (coercive vs. persuasive, public vs. private; formal vs. informal) as guides to text analysis and classification, and search for latent meanings.

At this point, it is worth saying that although this research used a theoretical codification as a guide, instead of an inductive codification, the formation of the themes took place inductively. This is because the codes coming from the theory served to group similar texts, and not to frame them to previously defined themes as it would be in a template analysis. This type of approach to theoretical coding is recommended when there is a specific theoretical interest of the researcher (Braun \& Clarke, 2006), as in the case in question, in which we wanted to understand the themes of enforcement in administration from the perspective of the theory of regulation.

At this stage, two researchers printed and categorized the texts manually and independently. After this initial stage, the classifications were confronted and discussed until a final classification was reached. This procedure was adopted due to being one of the strategies recommended by the literature to improve the process and ensure coding reliability (Crabtree \& Miller, 1999).

It is worth mentioning that although there are a number of software available for thematic analysis, such as NVivo and Atlas TI, with functionalities mainly for conducting thematic analysis of the template type, which have a certain similarity with a content analysis, we did not use them in this research. We adopted this procedure because the intended thematic analysis did not focus on textual exploration itself, but rather on the observation of latent codes. Moreover, the volume of texts was not so extensive as to make the use of software analysis essential.

3. Search for themes: The focus is to analyze the codes taking into account how they are combined in order to form comprehensive themes (Braun \& Clarke, 2006). In the present research, the analysis of the codes led to the identification of four groups of texts with homogeneous characteristics.

4. Review of themes: The objective is to verify whether the possible themes have internal homogeneity and external heterogeneity, that is, whether the codes are properly assigned and the themes have a common core that makes them equal and distinguishes them from the others (Braun \& Clarke, 2006). This was done by reviewing the codes, as well as by searching for a conductive line that would make the themes obtain uniqueness.

5. Naming themes: At this point, the author must question the essence of each theme and thus build a concise, strong, and informative name for each of them (Terry et al., 2017). At this stage, we analyzed the central mechanisms of each theme and from them we specified four types of enforcement: punitive, competitive, market, and cultural. The following table shows the allocation of the 31 articles selected in the Web of Knowledge database according to the four themes identified.

6. Production of the report: This stage consists of making an analytical and contextualized narrative of the literature on the themes identified (Clarke \& Braun, 2013). This is done in the following topic, in which the four types are detailed.

Table 2. Thematic distribution of studies on anti-corruption enforcement in the area of Administration.

\begin{tabular}{|c|c|c|c|c|}
\hline \multirow{2}{*}{ Thematic } & \multirow{2}{*}{ Theoretical } & \multicolumn{2}{|c|}{ Theoretical-empirical } & \multirow[b]{2}{*}{ Total } \\
\hline & & Qualitative & Quantitative & \\
\hline Punitive enforcement & 5 & 0 & 4 & 9 \\
\hline Market enforcement & 1 & 1 & 6 & 8 \\
\hline Competitive enforcement & 2 & 2 & 3 & 7 \\
\hline Cultural enforcement & 1 & 2 & 4 & 7 \\
\hline General total & 9 & 5 & 17 & 31 \\
\hline
\end{tabular}

Note. Source: from the survey. 
In addition to this guide of the technique application, which consists of a framework structure widely accepted in the literature, it is also possible to find additional recommendations to ensure the quality of the research. In this sense, King and Brooks (2018) recommend that at least one of three strategies must be used in thematic analysis: intercoder comparison, feedback from respondents, or audit trails. In the conduction of the research, we used the intercoder comparison in the category generation stage and in the review stage of the themes.

\section{ENFORCEMENT TYPOLOGIES}

Next, we present the four enforcement types identified from the thematic analysis in the administration literature.

\section{Punitive enforcement}

The first approach to the problem of organizational corruption comes from the work on the economics of crime. In this line, it was seek to model the incentives for criminal behavior based on the crime's probability of detection and punishment, as well as the value of punishment (Becker, 1968). Thus, the more likely it is to detect or the higher the punishments, the lower the incentives for the economic agent to engage in criminal activities. The literature shows, for example, that the increase in audit intensity or the amounts of fines results in a reduction in the levels of tax evasion (Chen, 2003) or a reduction in contractual values (Di Tella \& Schargrodsky, 2003). Also, when the levels of punishment are more severe, the level of cooperation between agents involved in corruption schemes (Abbink, Irlenbusch, \& Renner, 2002) tends to decrease.

On the other hand, detection and punishment generate budgetary costs, since they involve hiring more enforcement agents to monitor and prosecute criminal agents, as well as higher expenses for the administration of the prison system. Thus, within this line, the optimal level of enforcement consists in minimizing incentives for crime, subject to budgetary constraints (Polinsky \& Shavell, 2007). This implies that society will live with an ideal level of crime, since the harm caused by that crime would not offset the costs involved in its repression.

The literature has pointed out several solutions to try to optimize this trade-off between enforcement and budget. Regarding the probability of detection, it is proposed to increase the incentives for enforcement agents to be more productive or outsource the enforcement system to the private sector (Becker \& Stigler, 1974). In both cases, it can be reached a situation of excessive enforcement, with incentives for enforcement agents to persecute innocent in order to increase their rewards.
With regard to punishment, it is proposed as a solution to alternate custodial sentences for monetary penalties, since the latter would have the same inhibitory effect, but would not involve costs with the administration of the prison system (Polinsky \& Shavell, 2001). On the other hand, it is argued that replacing a custodial sentence with a monetary penalty, rather than inhibiting behavior, in the case of corruption, would simply induce corrupt agents to request greater amounts of corruption to compensate for the higher penalties.

Another problem with punishment enforcement, beyond budgetary constraints, is the possibility that there will be corruption of the enforcement agents themselves (Becker \& Stigler, 1974). It is argued that corrupt agents will seek to offer bribes to enforcement agents so that they do not perform the detection of devious practices. The propensity to offer bribes is as greater as the benefits obtained from corruption.

Therefore, there is a need to create mechanisms that ensure a non-corrupt enforcement system. One way that it is possible is by drawing incentives that encourage the agents of enforcement to be honest. Another way is to create and apply penalties to enforcement agents for corrupt behavior. The punishment, however, has a limit, because when it exceeds the remuneration or income of the agent, it has no effect. And that is the reality of developing countries (Rose-Ackerman, 2010). In addition, the possibility of punishment for the enforcement agents creates a disincentive to monitoring, then reducing the probability that they will find devious behaviors (Mookherjee \& Png, 1995).

One alternative proposed is to increase the reward of the enforcement agent to avoid cooptation by corrupting agents of the private sector. It is argued that higher salaries for enforcement agents can attract more easily honest people to this activity (Acemoglu \& Verdier, 1998). If the remuneration of enforcement officers is lower than that of other sectors, the enforcement function will tend to attract manly people who see corruption as a way to supplement the wage gap (Kugler, Verdier, \& Zenou, 2005). In addition, remuneration has been associated with higher detection rates. In this line, empirical works show that the increase in remuneration reduces the levels of corruption, especially in the monitoring phase (Di Tella \& Schargrodsky, 2003). The option for higher salaries, however, demands greater budgetary resources, which is not always available.

In addition to the typical budgetary constraint, in which society chooses not to invest more resources in enforcement agencies, there is the possibility of budget restriction forced by the interests of organizational groups involved in corruption, who lobby for a reduction in the enforcement budget (Damania, Fredriksson, \& Mani, 2004), especially when it is active. 
Finally, al though it is possible for punitive enforcement to induce permanent changes in the organizational behavioral (Abbink et al., 2002), the typical characteristic of this kind of enforcement system is to generate a temporary change of behavior, which once monitoring efforts cease, tends to return to previously inhibited corrupt behaviors.

\section{Market enforcement}

A second alternative to enforcement is the market's role as an agent of social pressure to ensure compliance with the law. In this sense, even if there are no formal contractual relations or a coercive public agent that guarantees the fulfillment of a legal duty, there are social mechanisms such as social pressures, ostracism, and reputation, which cause obligations to be fulfilled (Macaulay, 1963). These forces can arise from individual and collective pressures (Kandori, 1992) and are all the greater the more recurring the interactions between two agents (Klein \& Leffler, 1981; Williamson, 1979). Within this line, two mechanisms are discussed: the reward for integrity and the increase of transparency.

The principle of the reward for integrity is to create a counterpoint to the benefits that a company can receive from corruption. In this sense, the company would no longer engage in corruption to the extent that the market recognized the company as honest and decided to reward it for this behavior (O'Higgins, 2006). This reward for honesty can come from shareholders who recognize the company as more honest and thus pay a premium in the purchase of shares; financial institutions, which see non-corrupt clients as with less credit risk and, as a result, offer lower funding costs; or by the government, which creates incentives for companies that adopt anti-corruption practices and have no historic of involvement in corruption scandals.

Empirical research shows that companies are sensitive to these market pressures in decisions to engage in corruption schemes and that is reflected in their disclosure policies (Healy \& Serafeim, 2016). That is seen in the codes of ethics and anti-corruption measures, which present more operational details of policies adopted and are much higher than other business codes, such as environmental codes and work codes, denoting a greater concern with the implementation of such kind of codes (Gordon \& Miyake, 2001).

In this line, discussions arise about the ideal model of certification of anti-corruption practices, in order to prevent the market from being mistaken by merely symbolic actions (Pierce \& Toffel, 2013). In this sense, there are many possibilities, with certification being voluntary or mandatory, with self-certification or certification by a third party, with certification costs paid by honest companies or infringing companies. The mandatory certification model by third parties, with costs paid by companies with bad practices, is considered the most efficient (Baksi \& Bose, 2007).

There is also literature that recommends increasing transparency, both public and private, as a means of increasing the probability of deviation detection by the market. Along these lines, greater access of the population to the internet and transparency laws are associated with a reduction in corruption rates (Elbahnasawy, 2014). The same happens with the disclosure of income and assets of public servants (Gong, 2011).

On the other hand, the certification of clean companies and greater transparency have very limited effects if not accompanied by a cultural change by the market, in order to develop monitoring habits and reward non-corrupt companies (Larbi, 2007).

There is also evidence that there is complementarity between punitive enforcement and market enforcement. In this line, studies show that after the punishment of acts of fraud by government agencies, there is improvement in the level of information and reduction of the level of profit management (Fan, Guan, Li, \& Yang, 2014). This improvement is an attempt to compensate for the negative effects that the punishment received generates on the valuation models used by shareholders and financing agencies, since in these models there is a tendency to discount the risk associated with future events of corruption in the calculation of present value (Healy \& Serafeim, 2016).

Finally, there are studies comparing models of punitive enforcement and market enforcement. The results show that direct supervision is generally not associated with a reduction in levels of corruption. The market supervision model, with the government agent overseeing only disclosure policy, is associated with a greater reduction in levels of corruption (Beck, Demirgüç-Kunt, \& Levine, 2006). To justify these results, it is argued that direct supervision is subject to regulatory capture and market supervision is not.

\section{Competitive enforcement}

It is possible to think a third approach to enforcement from the competition structure of the market (Svensson, 2005). It is argued that if all companies competed in a free market, due to the pressures exerted by competition, the profits of companies would decrease, leaving no room for bribe payments (Otáhal, 2014). In this sense, studies show that there are higher levels of bribery payments in countries with low levels of competition or with greater government intervention in the economy (Clarke \& Xu, 2004). 
There is, however, some controversy in the causal relationship between competition and corruption. Some studies point the increase in competitiveness as a consequence of less corrupt environments. Thus, the reduction of the bureaucrat's power in relation to the imposition of market restrictions would result in less opportunities to extract rents for the exploitation of public services, giving more space to competition (Emerson, 2006). Similarly, reducing levels of corruption would lead to greater incentives for companies to formalize and adopt information technology, thereby increasing their competitiveness (Sudhir \& Talukdar, 2015).

Moreover, in environments where corruption is widespread, there would be no effective economic advantage for companies to engage in corrupt activities, so that the payment of bribes would represent a cost that would affect business competitiveness (Fadahunsi \& Rosa, 2002). Along these lines, the studies show that the approval of anticorruption laws in countries with higher levels of corruption does not generate negative effects on the competitiveness of the industry (Geo-Jala \& Mangum, 2000), which suggests that there would be no economic advantage with corruption for companies before the approval of these laws.

Other studies show competitiveness as an intervening variable in the process of reducing corruption. In this sense, the literature indicates that exposure to international competition, measured by total imports, causes a reduction in the country's levels of corruption (Ades \& Di Tella, 1999). Similarly, domestic companies wishing to compete in less corrupt international markets need to reduce their exposures to corrupt activities to become more competitive and avoid damage to their images (Pierre, 2015).

Other studies, although not directly addressing the relationship between corruption and competitiveness, bring evidence that points to lower business tolerance to corrupt environments as market conditions become more restrictive. Along these lines, the evidence shows that to the extent that companies need public enforcement to give effectiveness to their contracts or need access to the credit market, there is pressure for them to formalize, which makes them more exposed to extortion practices by public bureaucrats (Sarte, 2000). This increased exposure makes corruption to gain a larger social dimension, affecting a larger contingent of companies, which can trigger political actions of the business environment to reduce the discretion of the public agent.

This greater exposure to the public sector is also related to the level of punitive enforcement, since as the levels of supervision and punishment of informal activities increase, so does the tendency of formalization of companies (Antunes \& Cavalcanti, 2007; Fisman \& Miguel, 2007; Sukiassyan \& Nugent, 2008).

\section{Cultural enforcement}

A fourth type of enforcement comes from studies on culture. Within an organizational perspective, culture is understood as a collective programming of the mind that differentiates the members of one category from the members of another category (Hofstede \& Minkov, 2010). Behavior within the patterns of shared conduct is acquired through socialization processes and becomes a well valued by the individual belonging to that culture, so that the breaking of this value represents a moral cost to the individual (Greif, 1994). This value assigned to a pattern of conduct acts as a behavior inducing or inhibitory mechanism.

A line of studies seeks to compare individuals who were raised in different environments, but who live in the same economic and institutional environment. In this sense, we highlight the work of Fisman and Miguel (2007), who analyzed the number of traffic violations committed in New York by diplomats. The authors found that individuals from more corrupt countries tended to commit more crimes than agents from less corrupt countries.

Another line seeks to perform experiments with groups of people in order to identify variations in behaviors. In this line, Shaw, Katsaiti and Pecoraro (2015) wanted to understand behavioral aspects related to the involvement of students in corruption. The authors found that the perception of the act as corrupt and the previous participation of the person in other acts of corruption are factors that explain the corrupt behavior.

There are studies that attribute this culture of corruption to specific segments of the population (Sööt, 2012), as well as studies that seek to identify elements of organizational culture as associated with devious behavior. Along these lines, evidence points out that private organizations, due to the more aggressive orientation toward profit, tend to exhibit devious behaviors more frequently than third-sector organizations (Becker, Kessler, \& McClellan, 2005).

Furthermore, companies that operate in environments with institutional voids or low regulation tend to develop a culture of informality, in which the exchange of favors and the offering of advantages are seen as ways to strengthen ties and increase the certainty of operations (Verbeke \& Kano, 2013). Similarly, in environments where reciprocity prevails among individuals, there is a higher incidence of corruption (Alon \& Hageman, 2017).

On the other hand, in companies where there is a culture of impersonality and professionalism, there is less tolerance for corruption. In this line, in small companies, because there is a culture strongly linked to the figure of the founder, there are higher levels of corruption than in 
large companies, where the culture of professionalism prevails (DeBacker, Heim, \& Tran, 2015). Similarly, agents of multinational companies, which generally have a higher degree of professionalism, tend to exhibit corrupt behaviors in lower frequency than employees of domestic companies, which tend to be less professionalized than multinationals (Braguinsky \& Mityakov, 2015).

The studies also point to organizations as agents capable of implementing practices that change cultural perceptions about corruption. Thus, the simple existence of an ethics committee, even if not effective, serves as a symbolic means capable of modifying the perception of organizational agents about organizational tolerance to corruption practices (Smith, 2003). Furthermore, the professionalization of the company, through the hiring of employees from multinationals with a strong culture of transparency, acts as a mechanism capable of changing the organizational culture of domestic companies through a socialization process (Braguinsky \& Mityakov, 2015).

\section{CONNECTIONS BETWEEN REGULATORY AND MANAGEMENT LITERATURE}

In the previous section, four forms were identified in which the term enforcement has been used in the literature of organizations. From the exposure, it is possible to perceive that they present different foundations, both in terms of enforcement characteristics and in relation to the mechanisms by which they induce behavior. In addition, from a stakeholder's perspective it is possible to infer that these forms of enforcement have stronger links with certain agents of interest. We present a systematization of the characteristics of these approaches below.

Table 3. Comparison of study modalities related to enforcement in the area of organizations.

\begin{tabular}{|c|c|c|c|c|}
\hline Enforcement typology & Punitive enforcement & Competitive enforcement & Market enforcement & Cultural enforcement \\
\hline Definition & $\begin{array}{l}\text { Compliance induction } \\
\text { based on punitive action. }\end{array}$ & $\begin{array}{l}\text { Compliance induction } \\
\text { based on the search for } \\
\text { efficiency. }\end{array}$ & $\begin{array}{l}\text { Compliance induction } \\
\text { based on resource } \\
\text { constraints. }\end{array}$ & $\begin{array}{l}\text { Compliance induction by } \\
\text { moral alignment to the } \\
\text { standard of conduct. }\end{array}$ \\
\hline Mechanism of action & $\begin{array}{l}\text { - Penalty } \\
\text { - Supervision }\end{array}$ & $\begin{array}{l}\text { - Production efficiency } \\
\text { - Access to markets }\end{array}$ & $\begin{array}{l}\text { - Volume of financial } \\
\text { resources } \\
\text { - Honesty reward }\end{array}$ & $\begin{array}{l}\text { - Beliefs and values } \\
\text { - Socialization processes }\end{array}$ \\
\hline Enforcement strategy & Coercive & Coercive & Persuasive & Persuasive \\
\hline Enforcement agent & Public and private & Private & Private & Private \\
\hline Enforcement relation & Formal & Informal & Informal & Informal \\
\hline Stakeholder involved & $\begin{array}{l}\text { - Government } \\
\text { - Regulatory agencies }\end{array}$ & $\begin{array}{l}\text { - Competitors } \\
\text { - Customers }\end{array}$ & $\begin{array}{l}\text { - Shareholders } \\
\text { - Banks }\end{array}$ & $\begin{array}{l}\text { - Employees } \\
\text { - Managers }\end{array}$ \\
\hline
\end{tabular}

Note. Source: Own elaboration.

According to this classification, it is possible to make some considerations. First, considering the enforcement strategy, it is possible to infer, by the recurrence of the arguments raised, that within the competitive and punitive approaches there is a tendency to approach enforcement in a perspective of coerciveness, whereas in market and cultural approaches there is a greater recurrence of persuasive approaches. In relation to formality, punitive and market enforcements tend to present a more formal characteristic, while the competitive and cultural a more informal perspective. This outlook is similar to other approaches in the literature (Armour, 2008; Frank, 1984). Thus, in an association of the administration and regulation literature, it is possible to present the following connection.

Table 4. Relationship between enforcement in the administration literature and in the regulatory literature.

\begin{tabular}{|c|c|c|}
\hline Strategy $\backslash$ Relationship & Coercive & Persuasive \\
\hline Formal & Punitive & --- \\
\hline Informal & Competitive & Market; Cultural \\
\hline
\end{tabular}

Note. Source: own elaboration. 
Another point that deserves to be highlighted is that in the administration literature there is a predominance of studies with a private focus, with an association of public enforcement with punitive enforcement. This perspective seems to reinforce the idea that in literature there is an attempt to seek approaches that are less dependent on the government budget (Batory, 2012). Another explanation for this relationship may be associated with the fact that management seeks a perspective that contemplates several agents (stakeholders), not focusing only on a public and private distinction (Freeman, 1984).

\section{GENERAL DISCUSSION}

In the present work, we sought to situate the use of enforcement terminology in management studies within the perspective of the theory of enforcement from the regulatory literature. For this, initially, we identified the dimensions related to enforcement in the regulatory literature, following the identification of theoretical lines related to anti-corruption enforcement in organizational studies, and ending with a discussion of the interrelations between these two literatures.

As a result, it was possible to identify four distinct types of the term enforcement in the area of administration, which have different characteristics from the point of view of the enforcement dimensions of the regulatory literature. Thus, it was possible to achieve the proposed objective. The evidence of these characteristics contributes to the better use of terminology in the applied studies, and points to possible ways to expand the literature.

In this sense, from the present work, future studies may seek to develop theories that relate the types of enforcement identified with organizational phenomena such as financial performance, legitimacy, transaction costs, organizational culture, among other possibilities. Another way for future studies is the investigation of measures to quantify the enforcement dimensions identified in the present paper in order to measure the degree of occurrence of each type of enforcement and subsidize empirical work. In addition, empirical studies can test the effectiveness of each of the types of enforcement identified in order to provide guidance for practical applications in the corporate environment.

Furthermore, it is worth to observe that there is a growing search for alternative mental models, which seek to understand the behavior of the agent not only in a rational utilitarian perspective, but also in an institutional and cultural one (Fisman \& Miguel, 2007). In this sense, it is shown as promising to investigate behavioral approaches, which are still residual and more recent in relation to punitive enforcement. In addition to this perspective, the present work has some possible lines of empirical theoretical advancement.

One possibility of research based on this systematization is to analyze the extent to which these dimensions complement each other or show themselves as rivals. There are studies, for example, that point to the reciprocal influence between coercive strategies and those of persuasion (Liu et al., 2018). This perspective can be expanded to investigate, for example, the extent to which the degree of formality can affect the propensity of informal adoption of an anti-corruption practice, or how the punitive model is associated with the cultural model.

Another possibility of investigation is to analyze the costs associated with each approach, in order to perform a cost-benefit analysis of the various perspectives (Cohen, 2000). This is because while the budgetary costs of a public coercive approach are clear, it is also necessary to consider that there are costs associated with private enforcement approaches, such as agency costs, transaction costs, and even implementation costs of monitoring strategies.

As a last suggestion, considering agents with multiple rationalities, it is possible to investigate to what degree these various approaches interact together in determining the behavior of agents (Glicksman \& Earnhart, 2006). In this sense, it would be interesting to investigate whether contextual aspects can cause one or another approach to be more present in the environment and have a greater degree of effectiveness on behavior formation.

Finally, it is worth mentioning that the present study of typological classification, as well as any study of this nature, presents as main limitation the theoretical approach used, which contributed to the final form of the types of enforcement identified. This limitation, however, does not invalidate the study, since it presents the perspective from an outlook of analysis. Future studies may propose, within other theoretical approaches, typological alternatives to the same research problem, with which this typology can be contrasted. 


\section{REFERENCES}

Abbink, K., Irlenbusch, B., \& Renner, E. (2002). An experimental bribery game. Journal of Law, Economics, and Organization, 18(2), 428-454. https://doi.org/10.1093/jleo/18.2.428

Acemoglu, D., \& Verdier, T. (1998). Property rights, corruption and the allocation of talent: A general equilibrium approach. The Economic Journal, 108(450), 1381-1403. https://doi.org/10.1111/1468-0297.00347

Ades, A., \& Di Tella, R. (1999). Rents, competition, and corruption. The American Economic Review, 89(4), $982-$ 993. https://doi.org/10.1257/aer.89.4.982

Alon, A., \& Hageman, A. M. (2017). An institutional perspective on corruption in transition economies. Corporate Governance: An International Review, 25(3), 155-166. https://doi.org/10.1111/corg.12199

Antunes, A. R., \& Cavalcanti, T. (2007). Start up costs, limited enforcement, and the hidden economy. European Economic Review, 51(1), 203-224. https://doi.org/10.1016/j.euroecorev.2005.11.008

Armour, J. (2008). Enforcement strategies in UK corporate governance: A roadmap and empirical assessment. In A. M. Pacces (Ed.), The law and economics of corporate governance (Chap. 5). Cheltenham, UK: Edward Elgar Publishing.

Ashforth, B. E., Gioia, D. A., Robinson, S. L., \& Trevino, L. K. (2008). Re-viewing organizational corruption. Academy of Management Review, 33(3), 670-684. https://doi.org/10.5465/amr.2008.32465714

Bacharach, S. B. (1989). Organizational theories: Some criteria for evaluation. The Academy of Management Review, 14(4), 496-515. https://doi.org/10.2307/258555

Bakos, Y., \& Dellarocas, C. (2011). Cooperation without enforcement? A comparative analysis of litigation and online reputation as quality assurance mechanisms. Management Science, 57(11), 1944-1962. https://doi.org/10.1287/mnsc. 1110.1390

Baksi, S., \& Bose, P. (2007). Credence goods, efficient labelling policies, and regulatory enforcement. Environmental and Resource Economics, 37(2), 411-430. https://doi.org/10.1007/s10640-006-9032-0

Batory, A. (2012). Why do anti-corruption laws fail in Central Eastern Europe? A target compliance perspective. Regulation \& Governance, 6(1), 66-82. https://doi.org/10.1111/j.1748-5991.2011.01125.x

Beck, T., Demirgüç-Kunt, A., \& Levine, R. (2006). Bank supervision and corruption in lending. Journal of Monetary Economics, 53(8), 2131-2163. https://doi.org/10.1016/j.jmoneco.2005.10.014

Becker, D., Kessler, D., \& McClellan, M. (2005). Detecting medicare abuse. Journal of Health Economics, 24(1), 189210. https://doi.org/10.1016/j.jhealeco.2004.07.002

Becker, G. S. (1968). Crime and punishment: An economic approach. Journal of Political Economy, 76(2), 169-217. Retrieved from http://www.jstor.org/stable/1830482
Becker, G. S., \& Stigler, G. J. (1974). Law enforcement, malfeasance, and compensation of enforcers. The Journal of Legal Studies, 3(1), 1-18. https://doi.org/10.1086/467507

Braguinsky, S., \& Mityakov, S. (2015). Foreign corporations and the culture of transparency: Evidence from Russian administrative data. Journal of Financial Economics, 117(1), 139-164. https://doi.org/10.1016/j.jfineco.2013.02.016

Braun, V., \& Clarke, V. (2006). Using thematic analysis in psychology. Qualitative Research in Psychology, 3(2), 77 101. https://doi.org/10.1191/1478088706qp063oa

Braun,V., \&Clarke,V.(2016).(Mis)conceptualising themes, thematic analysis, and other problems with Fugard and Potts'(2015) sample-size tool for thematic analysis. International Journal of Social Research Methodology, 19(6), 739-743. https://doi.org/10.1080/13645579.2016.1195588

Burbank, S. B., Farhang, S., \& Kritzer, H. M. (2013). Private enforcement. Lewis o Clark Law Review, 17, 637-722. Retrieved from https://scholarship.law.umn.edu/faculty articles/1

Burrel, G. (2006). Ciência normal, paradigmas, metáforas, discursos e genealogia da análise. In S. Clegg, C. Hardy, W. Nord (Eds.), Handbook de estudos organizacionais: Modelos de análise e novas questóes em estudos organizacionais (Chap. 17, pp. 437-460). Sáo Paulo: Atlas

Carr, I. (2007). Corruption, legal solutions and limits of law. International Journal of Law in Context, 3(3), 227-255. https://doi.org/10.1017/S1744552307003035

Carson, L. D., \& Prado, M. M. (2014). Mapping corruption \& its institutional determinants in Brazil [IRIBA Working Paper nr. 8]. International Research Initiative on Brazil and Africa, Manchester, UK. Retrieved from http://www. brazil4africa.org/wp-content/uploads/publications/working papers/IRIBA WP08 Mapping Corruption and its Institutional Derminants in Brazil.pdf

Caza, A. (2012). Typology of the eight domains of discretion in organizations. Journal of Management Studies, 49(1), 144177.

Chen, B.-L. (2003). Tax evasion in a model of endogenous growth. Review of Economic Dynamics, 6(2), 381-403. https://doi.org/10.1016/S1094-2025(03)00002-4

Clarke, G. R. G., \& Xu, L. C. (2004). Privatization, competition, and corruption: How characteristics of bribe takers and payers affect bribes to utilities. Journal of Public Economics, 88(9-10), 2067-2097. https://doi.org/10.1016/j.jpubeco.2003.07.002

Clarke, V., \& Braun, V. (2013). Teaching thematic analysis: Overcomingchallengesanddevelopingstrategiesforeffective learning. The Psychologist, 26(2), 120-123. Retrieved from http://www.thepsychologist.org.uk/archive/archive home. cfm?volumeID=26\&editionID=222\&ArticleID=2222

Clarke, V., \& Braun, V. (2017). Thematic analysis. The Journal of Positive Psychology, 12(3), 297-298. https://doi.org/10.1080/17439760.2016.1262613 
Cohen, M. A. (2000). Empirical research on the deterrent effect of environmental monitoring and enforcement. Environmental Law Reporter News and Analysis, 30(4), 10245-10252. Retrieved from http://www.oecd.org/environment/outreach/33947732.pdf

Conaway, R. N., \& Wardrope, W. J. (2010). Do their words really matter? Thematic analysis of US and Latin American CEO letters. International Journal of Business Communication, 47(2), 141-168. https://doi.org/10.1177\%2F0021943610364523

Crabtree, B. F., \& Miller, W. L. (1999). Doing qualitative research. Thousand Oaks, CA: Sage Publications.

Crossan, M. M., \& Apaydin, M. (2010). A multidimensional framework of organizational innovation: A systematic review of the literature. Journal of Management Studies, 47(6), 1154-1191. https://doi.org/10.1111/j.1467-6486.2009.00880.x

Damania, R., Fredriksson, P. G., \& Mani, M. (2004). The persistence of corruption and regulatory compliance failures: Theory and evidence. Public Choice, 121(3), 363390. https://doi.org/10.1007/s11127-004-1684-0

DeBacker, J., Heim, B. T., \& Tran, A. (2015). Importing corruption culture from overseas: Evidence from corporate tax evasion in the United States. Journal of Financial Economics, 117(1), 122-138. https://doi.org/10.1016/j.jfineco.2012.11.009

Delbridge, R., \& Fiss, P. C. (2013). Editors' comments: Styles of theorizing and the social organization of knowledge. Academy of Management Review, 38(3), 325-331. https://doi.org/10.5465/amr.2013.0085

Di Tella, R., \& Schargrodsky, E. (2003). The role of wages and auditing during a crackdown on corruption in the city of Buenos Aires. The Journal of Law and Economics, 46(1), 269-292. https://doi.org/10.1086/345578

Doty, D. H., \& Glick, W. H. (1994). Typologies as a unique form of theory building: Toward improved understanding and modeling. Academy of Management Review, 19(2), 230251. https://doi.org/10.5465/amr.1994.9410210748

Earnhart, D. H., \& Glicksman, R. L. (2015). Coercive vs. cooperative enforcement: Effect of enforcement approach on environmental management. International Review of Law and Economics, 42, 135-146. https://doi.org/10.1016/j.irle.2015.02.003

Elbahnasawy, N. G. (2014). E-government, internet adoption, and corruption: An empirical investigation. World Development, 57, 114-126. https://doi.org/10.1016/j.worlddev.2013.12.005

Ellickson, R. C. (1998). Law and economics discovers social norms. The Journal of Legal Studies, 27(S2), 537-552. https://doi.org/10.1086/468033

Emerson, P. M. (2006). Corruption, competition and democracy. Journal of Development Economics, 81(1), 193-212. https://doi.org/10.1016/j.jdeveco.2005.04.005

Fadahunsi, A., \& Rosa, P. (2002). Entrepreneurship and illegality: Insights from the Nigerian cross-border trade. Journal of Business Venturing, 17(5), 397-429. https://doi.org/10.1016/S0883-9026(01)00073-8
Fan, J. P., Guan, F., Li, Z., \& Yang, Y. G. (2014). Relationship networks and earnings informativeness: Evidence from corruption cases. Journal of Business Finance \& Accounting, 41(7-8), 831-866. https://doi.org/10.1111/jbfa.12078

Fisman, R., \& Miguel, E. (2007). Corruption, norms, and legal enforcement: Evidence from diplomatic parking tickets. Journal of Political Economy, 115(6), 1020-1048. https://doi.org/10.1086/527495

Fiss, P. C. (2011). Building better causal theories: A fuzzy set approach to typologies in organization research. Academy of Management Journal, 54(2), 393-420. https://doi.org/10.5465/amj.2011.60263120

Frank, N. (1984). Policing corporate crime: A typology of enforcement styles. Justice Quarterly, 1(2), 235-251. https://doi.org/10.1080/07418828400088131

Freeman, R. E. (1984). Strategic management: A stakeholder approach. Boston: Pitman.

Galang, R. M. N. (2012). Victim or victimizer: Firm responses to government corruption. Journal of Management Studies, 49(2), 429-462. https://doi.org/10.1111/j.1467-6486.2010.00989.x

Galbiati, R., \& Vertova, P. (2014). How laws affect behavior: Obligations, incentives and cooperative behavior. International Review of Law and Economics, 38, 48-57. https://doi.org/10.1016/j.irle.2014.03.001

Garoupa, N., \& Klerman, D. M. (2010). Corruption and private law enforcement: Theory and history. Review of Law \& Economics, 6(1), 75-96. Retrieved from https://ideas.repec.org/a/bpj/rlecon/v6y2010i1n3.html

Geo-Jala, M. A., \& Mangum, G. L. (2000). The foreign corrupt practices act's consquences for US trade: The Nigerian example. Journal of Business Ethics, 24(3), 245-255. https://doi.org/10.1023/A:1006025226862

Gioia, D. A., \& Pitre, E. (1990). Multiparadigm perspectives on theory building. Academy of Management Review, 15(4), 584-602. https://doi.org/10.5465/amr.1990.4310758

Glicksman, R. L., \& Earnhart, D. H. (2006). Depiction of the regulator-regulated entity relationship in the chemical industry: Deterrence-based vs. cooperative enforcement. William \& Mary Environmental Law and Policy Review, 31(3), 603-660. Retrieved from https://scholarship.law.wm.edu/wmelpr/vol31/iss3/2

Gong, T. (2011). An 'institutional turn' in integrity management in China. International Review of Administrative Sciences, 77(4), 671-686. https://doi.org/10.1177\%2F0020852311419391

Gordon, K., \& Miyake, M. (2001). Business approaches to combating bribery: A study of codes of conduct. Journal of Business Ethics, 34(3), 161-173. https://doi.org/10.1023/A:1012517622479 
Gormley, W. T., Jr. (1998). Regulatory enforcement styles. Political Research Quarterly, 51(2), 363-383. https://doi.org/10.1177\%2F106591299805100204

Gray, W. B., \& Shimshack, J. P. (2011). The effectiveness of environmental monitoring and enforcement: A review of the empirical evidence. Review of Environmental Economics andPolicy, 5(1),3-24.https://doi.org/10.1093/reep/req017

Greif, A. (1994). Cultural beliefs and the organization of society: A historical and theoretical reflection on collectivist and individualist societies. Journal of Political Economy, 102(5), 912-950. https://doi.org/10.1086/261959

Gunningham, N. (2010). Enforcement and compliance strategies. In R. Baldwin, M. Cave, M. Lodge (Eds.), The Oxford handbook of regulation. Oxford: Oxford University Press.

Hay, J. R., \& Shleifer, A. (1998). Private enforcement of public laws: A theory of legal reform. The American Economic Review, 88(2), 398-403. Retrieved from https://www.jstor.org/stable/116955

Healy, P. M., \& Serafeim, G. (2016). An analysis of firms' selfreported anticorruption efforts. The Accounting Review, 91(2), 489-511. https://doi.org/10.2308/accr-51191

Heeks, R., \& Mathisen, H. (2012). Understanding success and failure of anti-corruption initiatives. Crime, Law and Social Change, 58(5), 533-549. https://doi.org/10.1007/s10611-011-9361-y

Helland, E. (1998). The enforcement of pollution control laws: Inspections, violations, and self-reporting. Review of Economics and Statistics, 80(1), 141-153. https://doi.org/10.1162/003465398557249

Hofstede, G. J., \& Minkov, M. (2010). Cultures and Organizations: Software for the Mind (3rd ed.) New York: McGraw-Hill Education.

Jabareen, Y. R. (2006). Sustainable urban forms: Their typologies, models, and concepts. Journal of Planning Education and Research, 26(1), 38-52. https://doi.org/10.1177\%2F0739456X05285119

Jia, C., Ding, S., Li, Y., \& Wu, Z. (2009). Fraud, enforcement action, and the role of corporate governance: Evidence from China. Journal of Business Ethics, 90(4), 561-576. https://doi.org/10.1007/s10551-009-0061-9

Kaczmarek, S. C., \& Newman, A. L. (2011). The long arm of the law: Extraterritoriality and the national implementation of foreignbriberylegislation. InternationalOrganization, 65(4), 745-770. https://doi.org/10.1017/S0020818311000270

Kagan, R. A. (1989). Editor's introduction: Understanding regulatory enforcement. Law \& Policy, 11(2), 89-119. https://doi.org/10.1111/j.1467-9930.1989.tb00022.x

Kandori, M. (1992). Social norms and community enforcement. The Review of Economic Studies, 59(1), 63-80. https://doi.org/10.2307/2297925

Katou, A. A. (2013). The relationship between corrupt practices and organisational performance: An empirical investigation. International Journal of Business Governance and Ethics, 8(4), 323-347. https://doi.org/10.1504/IJBGE.2013.059162
King, N. (2012). Doing template analysis. In G. Symon, C. Cassell (Eds.), Qualitative organizational research: Core methods and current challenges (pp. 77-101). Thousand Oaks, CA: SAGE Publications.

King, N., \& Brooks, J. (2018). Thematic analysis in organisational research. In C. Cassell, A. L. Cunliffe, G. Grandy (Eds.), The SAGE handbook of qualitative business and management research methods: Methods and challenges (Chap. 14). Thousand Oaks, CA: SAGE Publications.

Kirchler, E. (1999). Reactance to taxation: Employers' attitudes towards taxes. The Journal of Socio-Economics, 28(2), 131 138. https://doi.org/10.1016/S1053-5357(99)00003-7

Klein, B., \& Leffler, K. B. (1981). The role of market forces in assuring contractual performance. Journal of Political Economy, 89(4), 615-641. https://doi.org/10.1086/260996

Kube, S., \& Traxler, C. (2011). The interaction oflegal and social norm enforcement. Journal of Public Economic Theory, 13(5), 639660. https://doi.org/10.1111/j.1467-9779.2011.01515.x

Kugler, M., Verdier, T., \& Zenou, Y. (2005). Organized crime, corruption and punishment. Journal of Public Economics, 89(9-10), 1639-1663. https://doi.org/10.1016/j.jpubeco.2004.05.005

Kusyk, S. M., \& Lozano, J. M. (2007). SME social performance: a four-cell typology of key drivers and barriers on social issues and their implications for stakeholder theory. Corporate Governance, 7(4), 502-515. https://doi.org/10.1108/14720700710820588

Lane, P. J., Koka, B., \& Pathak, S. (2002). A thematic analysis and criticalassessmentofabsorptivecapacity research. Proceedings of the Academy of Management Annual Meeting, Denver, CO. https://doi.org/10.5465/apbpp.2002.7516527

Lange, D. (2008). A multidimensional conceptualization of organizational corruption control. Academy of Management Review, 33(3), 710-729. https://doi.org/10.5465/amr.2008.32465742

Larbi, G. A. (2007). Between spin and reality: Examining disclosure practices in three African countries. Public Administration and Development, 27(3), 205-214. Retrieved from https:// etico.iiep.unesco.org/en/resource/between-spin-and-realityexamining-disclosure-practices-three-african-countries

Linstead, S., Maréchal, G., \& Griffin, R. W. (2014). Theorizing and researching the dark side of organization. Organization Studies, 35(2), 165-188. https://doi.org/10.1177\%2F0170840613515402

Liu, N., Van Rooij, B., \& Lo, C. W.-H. (2018). Beyond deterrent enforcement styles: Behavioural intuitions of Chinese environmental law enforcement agents in a context of challenging inspections. Public Administration, 96(3), 497-512. https://doi.org/10.1111/padm.12415

Luo, Y. (2005). An organizational perspective of corruption. Management and Organization Review, 1(1), 119-154. https://doi.org/10.1111/j.1740-8784.2004.00006.x

Macaulay, S. (1963). Non-contractual relations in business: A preliminary study. American Sociological Review, 28(1), 55-67. https://doi.org/10.2307/2090458 
Matitz, Q. R. S., \& Vizeu, F. (2012). Construção e uso de conceitos em estudos organizacionais: Por uma perspectiva social e histórica. Revista de Administraçâo Pública, 46(2), 577-598. https://doi.org/10.1590/S0034-76122012000200011

May, P., \& Burby, R. (1998). Making sense out of regulatory enforcement. Law \& Policy, 20(2), 157-182. https://doi.org/10.1111/1467-9930.00046

McAllister, L. K. (2010). Dimensions of enforcement style: Factoring in regulatoryautonomyand capacity. Law \& Policy,32(1),6178. https://doi.org/10.1111/j.1467-9930.2009.00308.x

Miles, R. E., Snow, C. C., Meyer, A. D., \& Coleman, H. J. (1978). Organizational strategy, structure, and process. Academy of Management Review, 3(3), 546-562. https://doi.org/10.5465/amr.1978.4305755

Mintzberg, H. (1979). The structuring of organizations: A synthesis of the research. Upper Saddle River, NJ: Prentice-Hall

Mooi, E. A., \& Gilliland, D. I. (2013). How contracts and enforcement explain transaction outcomes. International Journal of Research in Marketing, 30(4), 395-405. https://doi.org/10.1016/j.ijresmar.2013.04.003

Mookherjee, D., \& Png, I. P.-L. (1995). Corruptible law enforcers: How should they be compensated? The Economic Journal, 105(248), 145-159. https://doi.org/10.2307/2235324

Niknazar, P., \& Bourgault, M. (2017). Theories for classification vs. classification as theory: Implications of classification and typology for the development of project management theories. International Journal of Project Management, 35(2), 191-203. https://doi.org/10.1016/j.ijproman.2016.11.002

Osuagwu, L. (2012). Conceptualization of corruption in business organizations. American International Journal of Contemporary Research, 2(5), 18-25. Retrieved from http://www.aijcrnet.com/journal/index/185

Otáhal, T. (2014). Mises, Hayek and corruption. Journal of Business Ethics, 119(3), 399-404. https://doi.org/10.1007/s10551-013-1646-x

O'Higgins, E. R. (2006). Corruption, underdevelopment, and extractive resource industries: Addressing the vicious cycle. Business Ethics Quarterly, 16(2), 235-254. https://doi.org/10.1017/S1052150X00012823

Pertiwi, K. (2018). Contextualizing corruption: A crossdisciplinary approach to studying corruption in organizations. Administrative Sciences, 8(2), 12. https://doi.org/10.3390/admsci8020012

Pierce, L., \& Toffel, M. W. (2013). The role of organizational scope and governance in strengthening private monitoring. Organization Science, 24(5), 1558-1584. https://doi.org/10.1287/orsc.1120.0801

Pierre, N. (2015). Foreign direct investment: Rule of law and corruption. Asia-Pacific Journal of Financial Studies, 44(2), 281-297. https://doi.org/10.1111/ajfs.12089
Pinto, J., Leana, C. R., \& Pil, F. K. (2008). Corrupt organizations or organizations of corrupt individuals? Two types of organization-level corruption. Academy of Management Review, 33(3), 685-709. https://doi.org/doi/10.2307/20159431

Polinsky, A. M., \& Shavell, S. (2000). The economic theory of public enforcement of law. Journal of Economic Literature, 38(1), 45-76. https://doi.org/10.1257/jel.38.1.45

Polinsky, A. M., \& Shavell, S. (2001). Corruption and optimal law enforcement. Journal of Public Economics, 81(1), 1-24. https://doi.org/10.1016/S0047-2727(00)00127-4

Polinsky, A. M., \& Shavell, S. (2007). The theory of public enforcement of law. In A. M. Polinsky \& S. Shavell (Eds.), Handbook of Law And Economics (Chap. 6, pp. 403-454). Amsterdam: North Holland.

Porter, M. E. (1980). Competitive strategy: Techniques for analyzing industries and competition. New York: Free Press.

Posner, E. A. (2002). Law and social norms. Cambridge: MA: Harvard University Press.

Radcliffe, L. S. (2013). Qualitative diaries: Uncovering the complexities of work-life decision-making. Qualitative Research in Organizations and Management: An International Journal, 8(2). 163-180. http://doi.org/10.1108/qrom-04-2012-1058

Rechtschaffen, C. (1997). Deterrence vs. cooperation and the evolving theory of environmental enforcement. Southern California Law Review, 71(6), 1181-1272.

Rose-Ackerman, S. (2010). The law and economics of bribery and extortion. Annual Review of Law and Social Science, 6, 217-238. https://doi.org/10.1146/annurev-lawsocsci-102209-152942

Sarte, P.-D. G. (2000). Informality and rent-seeking bureaucracies in a model of long-run growth. Journal of Monetary Economics, 46(1), 173-197. https://doi.org/10.1016/S0304-3932(00)00020-9

Shaw, P., Katsaiti, M. S., \& Pecoraro, B. (2015). On the determinants of educational corruption: The case of Ukraine. Contemporary Economic Policy, 33(4), 698-713. https://doi.org/10.1111/coep.12097

Shepherd, C., \& Challenger, R. (2013). Revisiting paradigm(s) in management research: A rhetorical analysis of the paradigm wars. International Journal of Management Reviews, 15(2), 225-244. https://doi.org/10.1111/ijmr.12004

Smith, R. W. (2003). Enforcement or ethical capacity: Considering the role of state ethics commissions at the millennium. Public Administration Review, 63(3), 283-295. https://doi.org/10.1111/1540-6210.00290

Snow, C. C., \& Ketchen, D. J., Jr. (2014). Typology-driven theorizing: A response to Delbridge and Fiss. Academy of Management Review, 39(2), 231-233. https://doi.org/10.5465/amr.2013.0388

Sudhir, K., \& Talukdar, D. (2015). The "Peter Pan syndrome" in emerging markets: The productivity-transparency tradeoff in IT adoption. Marketing Science, 34(4), 500-521. https://doi.org/10.1287/mksc.2015.0921 
Sukiassyan, G., \& Nugent, J. B. (2008). Associations versus registration as alternative strategies of small firms. Small Business Economics, 31(2), 147-161. https://doi.org/10.1007/s11187-007-9085-7

Sööt, M.-L. (2012). The role of management in tackling corruption. Baltic Journal of Management, 7(3), 287-301. https://doi.org/10.1108/17465261211245463

Svensson, J. (2005). Eight questions about corruption. The Journal of Economic Perspectives, 19(3), 19-42. https://doi.org/10.1257/089533005774357860

Terry, G., Hayfield, N., Clarke, V., \& Braun, V. (2017). Thematic analysis. In W. S. Rogers, \& C. Willig (Eds.), The SAGE Handbook of Qualitative Research in Psychology (2nd ed., pp. 17-37). London: SAGE Publications

Torsello, D., \& Venard, B. (2016). The anthropology of corruption. Journal of Management Inquiry, 25(1), 34-54. https://doi.org/10.1177\%2F1056492615579081

\section{Authorship}

\section{Robson Fernandes Soares*}

Universidade Positivo, Programa de Mestrado e Doutorado em Administração

R. Prof. Pedro Viriato Parigot de Souza, no 5300, Campo Comprido, 81280-330, Curitiba, PR, Brazil.

E-mail address: robsoares88@gmail.com

(D) https://orcid.org/0000-0003-0890-9078

\section{Edson Ronaldo Guarido Filho}

Universidade Positivo, Programa de Mestrado e Doutorado em Administração

R. Prof. Pedro Viriato Parigot de Souza, no 5300, Campo Comprido, 81280-330, Curitiba, PR, Brazil.

E-mail address: edson.guarido@gmail.com

(D) https://orcid.org/0000-0001-7905-1596

* Corresponding Author

\section{Funding}

The authors reported that there is no financial support for the research in this article.

\section{Conflict of Interests}

The authors have stated that there is no conflict of interest.

\section{Plagiarism Check}

The RAC maintains the practice of submitting all documents approved for publication to the plagiarism check, using specific tools, e.g.: iThenticate.
Verbeke, A., \& Kano, L. (2013). The transaction cost economics (TCE) theory of trading favors. Asia Pacific Journal of Management, 30(2), 409-431. https://doi.org/10.1007/s10490-012-9324-6

Vitell, S. J., \& Hidalgo, E. R. (2006). The impact of corporate ethical values and enforcement of ethical codes on the perceived importance of ethics in business: A comparison of US and Spanish managers. Journal of Business Ethics, 64(1), 31-43. https://doi.org/10.1007/s10551-005-4664-5

Voermans, W. (2014). Motive-based enforcement. Revista Juridica da Presidência, 16(108), 17-38. https://doi.org/10.20499/2236-3645.RJP2014v16e108-39

Williamson, O. E. (1979). Transaction-cost economics: The governance of contractual relations. The Journal of Law and Economics, 22(2), 233-261. https://doi.org/10.1086/466942

Williamson, O. E. (1996). The mechanisms of governance. Oxford: Oxford University Press.

\section{Authors' Contributions}

$1^{\text {st }}$ author: conceptualization (lead); formal analysis (lead); investigation (lead); methodology (lead); validation (equal); writing-original draft (lead); writing-review \& editing (lead).

$2^{\text {nd }}$ author: conceptualization (supporting); formal analysis (supporting); methodology (supporting); validation (equal); writing-original draft (supporting); writing-review \& editing (supporting).

\section{Copyrights}

RAC owns the copyright to this content.

\section{Peer Review Method}

This content was evaluated using the double-blind peer review process. The disclosure of the reviewers' information on the first page, as well as the Peer Review Report, is made only after concluding the evaluation process, and with the voluntary consent of the respective reviewers and authors.

\section{Data Availability}

RAC encourages data sharing but, in compliance with ethical principles, it does not demand the disclosure of any means of identifying research subjects, preserving the privacy of research subjects. The practice of open data is to enable the reproducibility of results, and to ensure the unrestricted transparency of the results of the published research, without requiring the identity of research subjects. 